\title{
Comparison of conservative and radical surgery in the management of placenta previa percreta
}

\author{
Burak Sezgin $^{1}$ (D), Burcu Kasap ${ }^{1}$ (D), Eda Adeviye Şahin² (D) Aysun Camuzcuoğlu³ \\ Hakan Camuzcuoğlu ${ }^{4}$ \\ ${ }^{1}$ Department of Obstetrics and Gynecology, Faculty of Medicine, Mŭ̆la Sitkı Koçman University, Muğgla, Turkey \\ ${ }^{2}$ Clinic of Obstetrics and Gynecology, Fatih Medical Park Hospital, Istanbul, Turkey \\ ${ }^{3}$ Clinic of Obstetrics and Gynecology, Private Adatip Sakarya Hospital, Sakarya, Turkey \\ ${ }^{4}$ Private Clinic for Gynecologic Oncology, Sakarya, Turkey
}

\begin{abstract}
Objective: We aimed to compare the uterine sparing (US) surgery and hysterectomy for placenta previa percreta (PPP) management.

Methods: Data from PPP patients with anterior invasion who underwent US surgery and caesarean hysterectomy were retrospectively analyzed. The clinical and surgical outcomes of patients with PPP were compared according to the type of surgery.

Results: The mean intraoperative blood loss was lower in US surgery group than in caesarean hysterectomy group (1227.78 \pm 204.80 $\mathrm{ml}$ vs $1442.22 \pm 125.68 \mathrm{ml} ; \mathrm{p}=0.017)$. The hemoglobin drop was also significantly lower in the patients with US surgery $(1.87 \pm 0.68 \mathrm{~g} / \mathrm{dl}$ vs $2.88 \pm 1.04 \mathrm{~g} / \mathrm{dl} ; \mathrm{p}=0.026$ ). Moreover, the mean total transfusion rate was also significantly lower in the patients with US surgery $(1.33 \pm 0.87 \mathrm{U}$ vs $2.33 \pm 0.71 \mathrm{U}$; $\mathrm{p}=0.016)$.

Conclusion: Uterine sparing surgery reduces intraoperative blood loss and transfusion rate in PPP patients with anterior placental invasion compared to hysterectomy. The temporary blockage of bilateral uterine and uteroovarian arteries with Satinsky clamps may potentially contribute to the success of US surgery.
\end{abstract}

Keywords: Placental invasion anomaly, placenta percreta, placenta previa, Satinsky clamps, uterine sparing surgery.

\section{Introduction}

Placenta accreta spectrum is a serious condition that can develop due to abnormal trophoblastic invasion of the placenta towards the myometrium. ${ }^{[1]}$ It is associated with severe maternal morbidity. The guideline published by
Özet: Plasenta previa perkreta yönetiminde geleneksel ve radikal cerrahi operasyonun karşılaştırması

Amaç: Plasenta previa perkreta (PPP) yönetimi için uterus koruyucu cerrahi (UKC) ve histerektomiyi karşılaştırmayı amaçladık.

Yöntem: UKC ve histerektomi olan anterior invazyonlu PPP hastalarının verileri retrospektif olarak analiz edildi. PPP'li hastaların klinik ve cerrahi sonuçları, cerrahi operasyon türüne göre karşılaştırild.

Bulgular: UKC grubunda ortalama intraoperatif kan kaybi, sezaryen histerektomi grubuna kıyasla daha düşüktü $(1227.78 \pm 204.80$ ml'ye karşı $1442.22 \pm 125.68 \mathrm{ml} ; \mathrm{p}=0.017)$. Hemoglobin düşüşü, UKC yapılan hastalarda anlamlı şekilde daha düşüktü $(1.87 \pm 0.68$

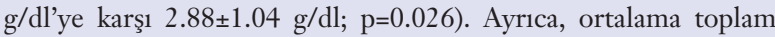
transfüzyon oranı da UKC grubundaki hastalarda anlamlı şekilde daha düşüktü $(1.33 \pm 0.87$ Ü’ye karşı $2.33 \pm 0.71 \ddot{U} ; \mathrm{p}=0.016)$.

Sonuç: Histerektomiye klyasla UKC, anterior plasental invazyonlu PPP hastalarında intraoperatif kan kaybını ve transfüzyon oranını azaltır. Bilateral uterusun ve utero-ovaryen arterlerin Satinsky klempleriyle geçici blokajı, UKC başarısına katkıda bulunma potansiyeline sahiptir.

Anahtar sözcükler: Plasental invazyon anomalisi, plasenta perkreta, plasenta previa, Satinsky klempleri, uterus koruyucu cerrahi.

the American College of Obstetricians and Gynecologists (ACOG) and the Society for Maternal-Fetal Medicine (SMFM) emphasized that such patients should take level $3-4$ care. ${ }^{[2]}$ Furthermore, the incidence of placenta adhesion anomalies increases in correlation with increased

Correspondence: Burak Sezgin, MD. Department of Obstetrics and Gynecology, Faculty of Medicine, Muğla Sıtkı Koçman University, Muğla, Turkey. e-mail: buraksezgin@yahoo.com / Received: November 4, 2020; Accepted: February 1, 2021

How to cite this article: Sezgin B, Kasap B, Adeviye Şahin E, Camuzcuoğlu A, Camuzcuoğlu H. Comparison of conservative and radical surgery in the management of placenta previa percreta. Perinatal Journal 2021;29(1):46-53. doi:10.2399/prn.21.0291008

ORCID ID: B. Sezgin 0000-0003-2938-5816; B. Kasap 0000-0002-1768-5320; E. Adeviye Şahin 0000-0003-4004-8167; 
caesarean section rates today. In a study made in China, which switched from one child to two children policy in 2011, the incidence of increta and percreta has been reported to rise from $0.18 \%$ to $0.78 \% .{ }^{[3]}$ In countries where the number of children has been accepted as social force, such as Turkey, the incidence of placenta percreta is estimated to be higher.

There are three types of placenta accreta spectrum. Those are, accreta, increta and percreta, which varies according to the degree of pathological invasion. Placenta percreta is the most serious form of these types. Thus, it causes intractable intrapartum and postpartum bleeding due to the deep invasion of the placenta into the adjacent structures of the myometrium and uterus. ${ }^{[4]}$ Postpartum hemorrhage in $65.9 \%$, transfusion requirement in $86.2 \%$, peripheral visceral injury in $14.3 \%$ and neonatal intensive care need in $54.5 \%$ of the patients with placenta percreta are indicated. ${ }^{[3]}$ Risk of placental insertion anomaly in patients with placenta previa in $3 \mathrm{rd}$ caesarean section was $40 \%$ and in 4 th it reaches $67 \% .{ }^{[5]}$ The combination of placenta percreta and placenta previa is thought to increase the aforementioned risks.

The management of placenta percreta requires a multidisciplinary approach and experience. Today, the most widely recommended approach is planned caesarean hysterectomy before the start of labor. ${ }^{[6]}$ But for patients who want to maintain fertility, uterine sparing (US) alternative approaches come to the fore. Several US approaches have been proposed to date based on the basis of reducing the amount of bleeding and complications. ${ }^{[4,7-10]}$ Nevertheless, both the patients and the obstetricians have a tendency to avoid placenta previa percreta (PPP) surgery, although there are several techniques have been developed for such cases. An optimal treatment for placenta accreta spectrum disorders has not yet been determined. In this study, we aimed to compare the effectiveness and the results of radical surgery versus US surgery using Satinsky clamps in the surgical management of PPP.

\section{Methods}

This retrospective study was approved by the local ethics committee for clinical research of Muğla Sitk1 Koçman University, Faculty of Medicine, Muğla, Turkey. Between March 2015 and January 2020, data from patients who underwent hysterectomy or US surgery for PPP were retrospectively analyzed. In our clinic practice, standard surgery for previa percreta patients is planned with hysterectomy. For patients who insisted on preserving her fertility, we performed US surgery after telling the risks of US surgery and taking the strict necessary approval form. The necessary information was obtained from the hospital database and patient files. Only those who had signed the informed consent at the time of medical evaluation were included in the present research.

During this period, 25 patients who preoperatively diagnosed as PPP were analyzed. Among those patients, 18 had anteriorly proved placenta percreta diagnosis intraoperatively and included to the study. Three patients had parametrial or posterior invasion anomaly of percreta, three patients who were not diagnosed as PPP during surgery were excluded. Medical records of one patient could not be found. A total of nine patients with US surgery and nine patients with hysterectomy were included (Fig. 1). Patients characteristics such as age, gravida, parity, body mass index

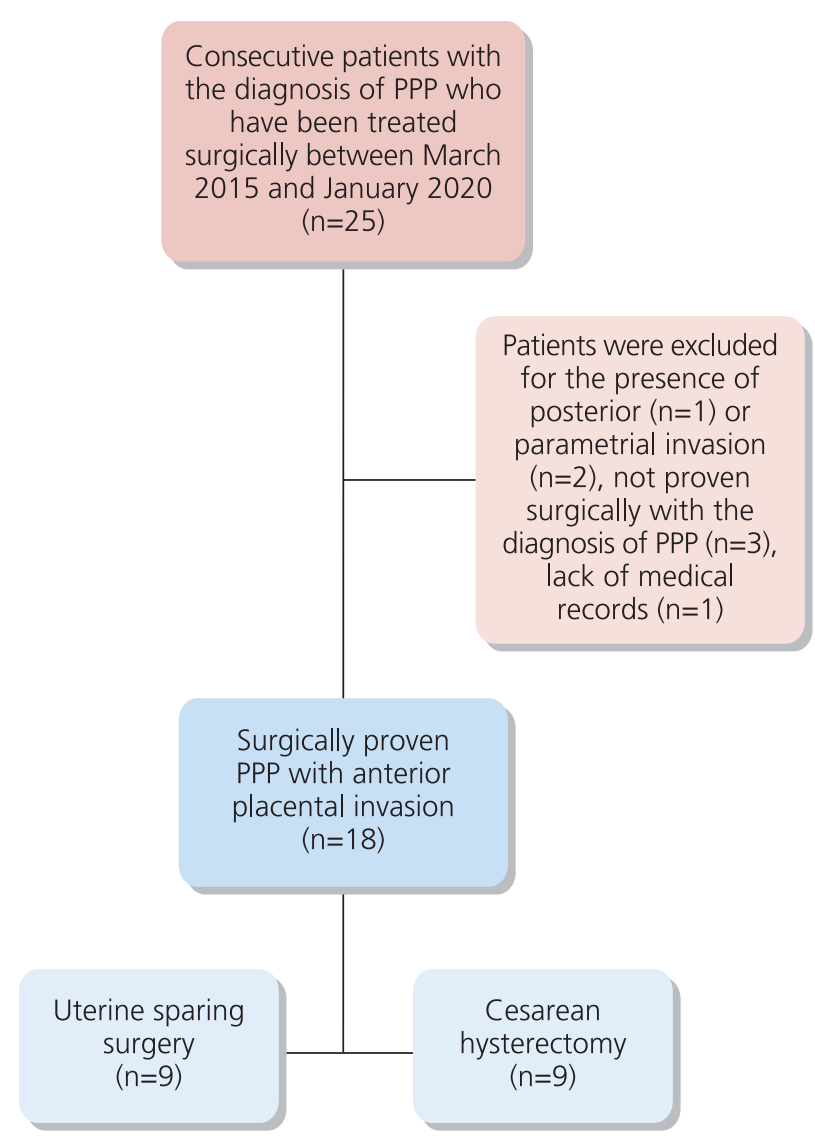

Fig. 1. Flowchart for selection of study population. 
(BMI), birth week, the number of previous caesarean sections, intraoperative blood loss, intraoperative complications (bladder, ureter, gastrointestinal system injuries), postoperative complications, preoperative hemoglobin, postoperative hemoglobin, hemoglobin decrease, total transfusion need and intensive care unit need were obtained from the hospital database.

The amount of intraoperative bleeding was calculated by adding the amount of blood detected in the aspirator to the weight difference of the wet and dry states of gauze and compresses. The hemoglobin decrease was calculated in $\mathrm{g} / \mathrm{dl}$ by subtracting the preoperative hemoglobin value from the postoperative hemoglobin value. Preoperative hemoglobin was calculated in $\mathrm{g} / \mathrm{dl}$ as the hemoglobin value obtained on the day before the operation. Postoperative hemoglobin was calculated in $\mathrm{g} / \mathrm{dl}$ as the hemoglobin value obtained 24 hours after the operation (default practice of our clinic). The duration of hospitalization was calculated in days from the first postoperative day until discharge time. The patients were grouped into the US group $(\mathrm{n}=9)$ and hysterectomy group ( $n=9)$. Patient demographics were described. Preoperative, intraoperative and postoperative surgical parameters were compared and analyzed.

Placental implantation site was evaluated with transabdominal, transvaginal and Doppler ultrasonography. Visualization of lacunae/turbulent lacunae flow and lack of a sonoluscent zone were diagnostic criteria used in imaging methods for the diagnosis of PPP.$^{[1]]}$ In some cases, a magnetic resonance imaging was taken to clarify the diagnosis of PPP. Detection of abnormally engorged vessels on the lower anterior surface of the uterus and abnormal vascularity exceeding the uterine serosa or reaching to surrounding organs during operation estab- lished the diagnosis of PPP. If bleeding occurred during follow-up period of the patients with PPP, caesarean section was performed without regard to the week of pregnancy. At 35-36 weeks of gestation, planned caesarean section was performed in women without any complications in obstetric follow-ups. Preoperative placental mapping with transabdominal ultrasonography was performed in all patients diagnosed with PPP. The reason for this was to perform the caesarean section without damaging the placenta during uterine incision. We reserved four units of erythrocyte suspension and four units of fresh frozen plasma preoperatively for all patients, which is the routine practice of our clinic.

\section{Surgical technique}

\section{Uterine sparing surgery}

The surgical procedure began with an infraumbilical midline incision to open the peritoneal cavity. Then longitudinal incision in the uterine fundus was performed for removal of the fetus. However, uterine fundus incision can be modified as slightly laterally according to the findings of placental mapping. This is very important to avoid any unnecessary injury to placenta. Then, fetus is removed immediately via reverse breech presentation. Umbilical cord is clamped and placenta is left in place. At this step, fundal incision is closed in a continuous manner. Before dissection of vesica from anterior wall of uterus, two Satinsky clamps are positioned on bilateral infundibulopelvic ligaments and another two Satinsky clamps are positioned gently on bilateral uterine arteries at the isthmic level for decreasing vascularization of the uterus (Fig. 2). This step is critical for more comfortable continuation of the rest of the surgical procedure. Then dissection of vesica from anterior wall is performed by
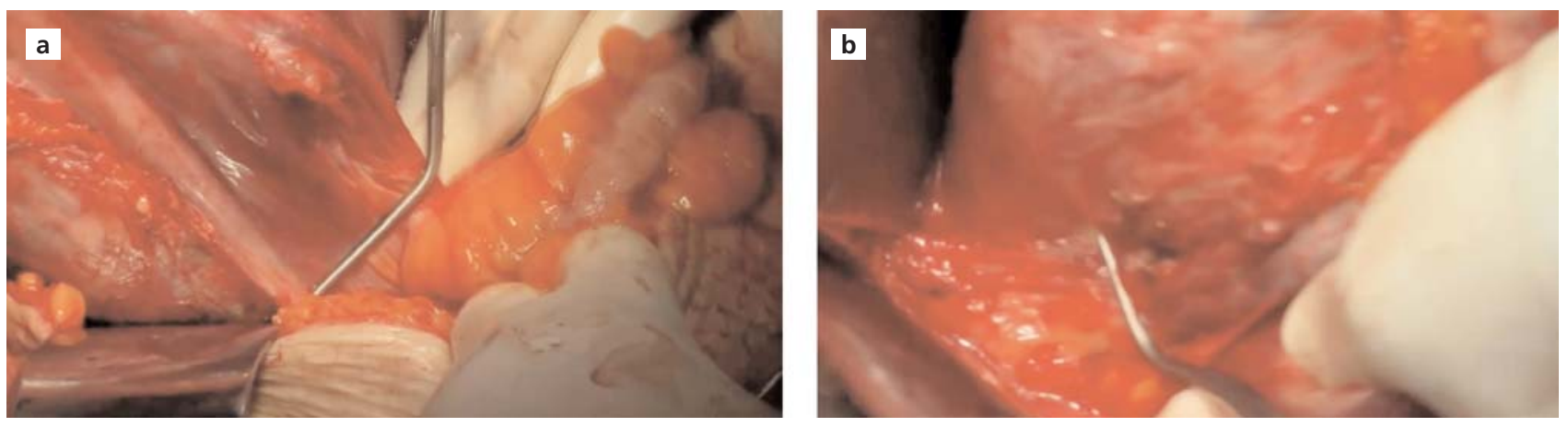

Fig. 2. (a) A Satinsky clamp is positioned on left infundibulopelvic ligament. (b) Another Satinsky clamp is positioned gently on left uterine artery. 
the help of electrocautery, right angle clamp and collet (Fig. 3). Sometimes we choose handle LigaSure sealing device for devascularization of aberrant vessels crossing vesica. After fully dissection of vesica, the lower end of the placental adhesion area was reached anteriorly. Afterwards, local resection of adherent placental part was performed. At this step, as left hand of surgeon controls the borders of adherent part inside the uterus, right hand with scalpel outside the uterus opens the borders of adherent placenta in a circular fashion. After resecting the placenta totally with adherent uterine wall, no:1/0 vicryl is used to suture uterine wall defect in a continuous locked fashion. Then all of the Satinsky clamps are removed. After sustaining normal vascularity of the uterus, we check and suture for extra bleeding parts. When hemostasis control is achieved, the abdominal wall is closed in accordance with its anatomical layers. All patients in US group underwent surgery as described above.

\section{Hysterectomy}

The surgical procedure applied in all patients who underwent hysterectomy is the same as described in the study of Camuzcuoğlu et al. ${ }^{[12]}$ The only difference is that internal iliac artery ligation was not applied in any patient in this study.

\section{Statistical analysis}

Statistical analyses were performed using Statistical Package for the Social Sciences software, version 23 (IBM Inc., Armonk, NY, USA). Shapiro-Wilk test was used to determine the distribution type. The data were expressed as the mean \pm standard deviation for normally distributed data, and as median [25th-75th percentiles]

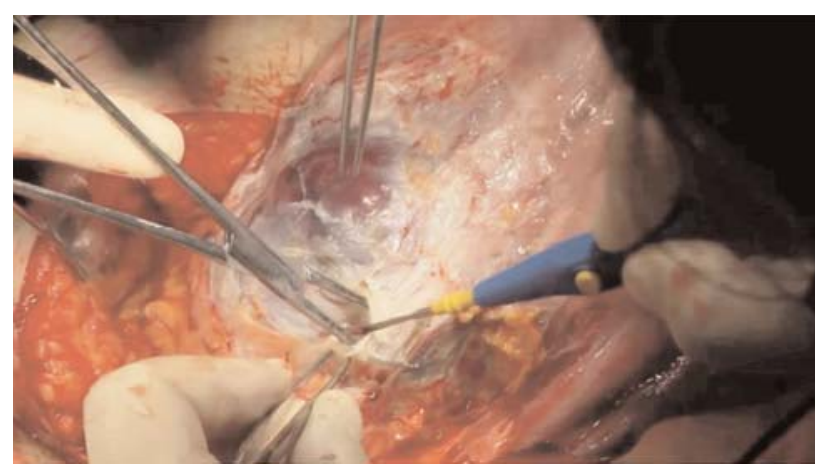

Fig. 3. Dissection of vesica from anterior wall of the uterus is performed by the help of electrocautery, right angle clamp and collet.

for non-normally distributed data. The significance of differences between the groups was determined using Mann-Whitney $U$ (for non-normally distributed data) and independent sample t-test (for normally distributed data). The chi-square analysis was done for categorical data. Post-hoc power analysis was done at the end of study taking transfusion rate as the main outcome variable. A p-value of less than 0.05 was considered statistically significant.

\section{Results}

The baseline demographic characteristics of the patients are listed in Table 1. The average age of patients in the two groups was similar (US group $34.78 \pm 2.11$ years vs hysterectomy group $35.67 \pm 2.29$ years; $\mathrm{p}=0.404)$. The mean BMI of patients in the two groups was also similar (US group $29.96 \pm 2.28$ vs hysterectomy group $28.97 \pm$ 2.99; $\mathrm{p}=0.442$ ). In US group, median number of caesare-

Table 1. Demographic characteristics of study participants.

\begin{tabular}{|c|c|c|c|}
\hline Variables & $\begin{array}{l}\text { Uterine sparing group }(n=9) \\
\text { Mean } \pm \text { SD* or } \\
\text { Median (25th-75th) }\end{array}$ & $\begin{array}{l}\text { Hysterectomy group }(n=9) \\
\text { Mean } \pm S D^{*} \text { or } \\
\text { Median (25th-75th) }{ }^{\dagger}\end{array}$ & p-value \\
\hline Age (years) & $34.78 \pm 2.11$ & $35.67 \pm 2.29$ & $0.404^{*}$ \\
\hline BMI $\left(\mathrm{kg} / \mathrm{m}^{2}\right)$ & $29.96 \pm 2.28$ & $28.97 \pm 2.99$ & $0.442^{*}$ \\
\hline Gravidity (n) & $3.44 \pm 0.89$ & $3.78 \pm 1.20$ & $0.512^{*}$ \\
\hline Parity (n) & $2.56 \pm 0.53$ & $3.00 \pm 1.11$ & $0.297^{*}$ \\
\hline Birth week (n) & $35(33-36)$ & 36 (35-37) & $0.154^{\dagger}$ \\
\hline Previous C/S (n) & $3(1.5-49)$ & $3(2-4)$ & $0.712^{+}$ \\
\hline
\end{tabular}

p $<0.05$ indicates statistical significance. Continuous variables are given as the mean and standard deviation or median [25th-75th]. BMI: body mass index; C/S: cesarean section; SD: standard deviation. ${ }^{*}$ Independent sample t-test; ${ }^{\dagger}$ Mann-Whitney U test. 
an section was three (range 1.5-4), as well as it was three (range 2-4) in hysterectomy group ( $\mathrm{p}=0.712)$. There was no significant difference in terms of birth weeks of two groups (US group 35 [range 33-36] weeks vs hysterectomy group 36 [range 35-37] weeks; $\mathrm{p}=0.154$ ).

The clinical and surgical outcomes of the two groups were compared and are documented in Table 2. The mean preoperative hemoglobin $(\mathrm{Hb})$ values in the US and hysterectomy groups were similar $(11.49 \pm 1.32 \mathrm{~g} / \mathrm{dl}$ vs $11.09 \pm 1.75 \mathrm{~g} / \mathrm{dl}$, respectively; $\mathrm{p}=0.592)$. However, postoperative $\mathrm{Hb}$ and $\mathrm{Hb}$ drop values were lower in the hysterectomy group ( $\mathrm{p}=0.027$ and $\mathrm{p}=0.026$, respectively). The mean intraoperative blood loss volume was significantly lower in the US group $(1227.78 \pm 204.80 \mathrm{ml}$ vs $1442.22 \pm 125.68 \mathrm{ml} ; \mathrm{p}=0.017)$. The mean total transfusion rate was significantly lower in the US group than in the hysterectomy group $(1.33 \pm 0.87 \mathrm{U}$ vs $2.33 \pm 0.71 \mathrm{U}$; $\mathrm{p}=0.016$ ). No cases of intraoperative complications in terms of ureter and bowel injury were reported in either group. However, one of the nine patients in US group and one in hysterectomy group had bladder injury $(p=0.303)$. Moreover, one of the nine patients in US group and two of the patients in hysterectomy group had intensive care unit need $(\mathrm{p}=0.134)$.

\section{Discussion}

In this study, we evaluated and compared the results of US surgery and hysterectomy performed in the PPP cases in our clinic. The main result of the study was that intraoperative bleeding, $\mathrm{Hb}$ drop and total transfusion rate were significantly less in patients undergoing US surgery than in patients undergoing radical surgery. Moreover, there was no difference between the two groups in terms of complications. The results of this study may contribute to the literature in PPP cases with anterior invasion who want to preserve their fertility.

Today, with increased caesarean rates, the risk of encountering with placenta percreta is increasing steadily. Although the classic treatment is hysterectomy, uterine protective approaches has gained popularity in recent years. In particular, in societies where continuing fertility has utmost importance for women's social status, the option of hysterectomy may come across as a problem as it causes cessation of fertility. In 2004, Palacious et al. were able to perform US surgery on 50 out of 68 anterior percreta cases. ${ }^{[7]}$ In their study published in 2020, the same authors reported that hysterectomy can be prevented by $80 \%$ in placenta accreta spectrum disorders. ${ }^{[13]}$ Local resection and reconstruction methods have been modified by many authors and have been successfully applied in placenta percreta cases until today. ${ }^{[4,7,10,14-18]}$ We also applied local resection and reconstruction methods in all cases where we have performed US surgery, and the uterus has been preserved in all of the cases. All of these cases were anterior percreta. The placental invasion site is probably one of the most important factors in deciding to perform uterine protective approach. In particular, if there is an invasion of the placenta to the parametrium or posterior of the uterus, the US surgery is not a preferred approach. Because the risk of sudden intractable bleeding and mortality risk is

Table 2. Clinical data of the studied groups.

\begin{tabular}{|c|c|c|c|}
\hline Variables & $\begin{array}{l}\text { Uterine sparing group }(n=9) \\
\text { Mean } \pm S D^{*}\end{array}$ & $\begin{array}{l}\text { Hysterectomy group }(n=9) \\
\text { Mean } \pm \text { SD* }\end{array}$ & p-value \\
\hline Preop Hb (g/dl) & $11.49 \pm 1.32$ & $11.09 \pm 1.75$ & $0.592^{*}$ \\
\hline Postop Hb (g/dl) & $9.73 \pm 0.96$ & $8.21 \pm 1.62$ & $0.027^{*+}$ \\
\hline $\mathrm{Hb}$ drop & $1.87 \pm 0.68$ & $2.88 \pm 1.04$ & $0.026^{*+}$ \\
\hline Intraoperative blood loss (ml) & $1227.78 \pm 204.80$ & $1442.22 \pm 125.68$ & $0.017^{*+}$ \\
\hline Total transfusion (unit) & $1.33 \pm 0.87$ & $2.33 \pm 0.71$ & $0.016^{*+}$ \\
\hline Bladder injury (n) (\%) & $1 / 9(11.11)$ & $1 / 9(11.11)$ & $0.303^{\ddagger}$ \\
\hline Ureter injury (n) (\%) & - & - & \\
\hline Bowel injury (n) (\%) & - & - & \\
\hline ICU need $(n)(\%)$ & $1 / 9(11.11)$ & $2 / 9(22.22)$ & $0.134^{\ddagger}$ \\
\hline
\end{tabular}

Continuous variables are given as the mean and standard deviation. Categorical variables are given as the number (percentages). Hb: hemoglobin; Postop: postoperative; Preop: preoperative; SD: standard deviation. ${ }^{*}$ Independent sample t-test; ${ }^{\dagger} p<0.05 ;{ }^{\ddagger}$ Chi-square analysis. 
high. Here, it can be said that US surgery can be performed on patients insisted keeping their fertility, especially in anterior percreta cases.

Sudden bleeding in percreta surgery makes exploration difficult and, increases the mortality and the complications. It is very important to minimize intraoperative bleeding in order to achieve successful outcomes at this surgery. A wide variety of methods have been applied to reduce intraoperative bleeding. These methods include applications requiring interventional radiology such as prophylactic balloon catheter occlusion (uterine artery, internal iliac artery, common iliac artery, aorta), embolization of uterine or internal iliac artery. ${ }^{[3,11,19-23]}$ Although there is not enough data in the literature on the effectiveness of these methods, there are cases where serious complications have been reported in the literature. ${ }^{[2,24,25]}$ Our hospital does not have an interventional radiologist experienced in these issues. That's why we have not had an experience on this. Apart from these methods, uterine artery ligation, internal iliac artery ligation, uterine tourniquet, uteroovarian ligament ligation, stapler use in hysterotomy, intracavitary suture methods has been applied by several authors to reduce the amount of intraoperative bleeding. ${ }^{[9,12,14-18]}$ In percreta patients who underwent hysterectomy, Turan et al., Palacious et al. and Sumigama et al. reported an average amount of bleeding as $1950 \mathrm{ml}, 2000 \mathrm{ml}$ and $12,140 \mathrm{ml}$, respectively. ${ }^{[9,11,13]}$ Acar et al. and Donna et al. reported the average amount of bleeding in placenta accreta spectrum disorders with US surgery as $1350 \mathrm{cc}$, $1200 \mathrm{cc}$, respectively. ${ }^{[17,22]}$ The majority of these reported cases consist of accreta and increta cases. In our study, although, all cases were placenta percreta, the mean intraoperative bleeding was $1442.22 \pm 125.68 \mathrm{ml}$ in the hysterectomy group and $1227.78 \pm 204.80 \mathrm{ml}$ in the US group. Here we can say that temporary clamping of bilateral uterine arteries and infundibulopelvic ligaments after removal of the fetus is an effective method to decrease intraoperative bleeding.

In our series, we found that $\mathrm{Hb}$ decrease was $1.87 \pm 0.68 \mathrm{~g} / \mathrm{dl}$ in US group and $2.88 \pm 1.04 \mathrm{~g} / \mathrm{dl}$ in hysterectomy group. These values directly affect the transfusion requirement. In their placenta accreta spectrum series where they performed segmental resection, Cirpan et al., Karaman et al. and Karaçor et al. reported an average of 4.18 units, 4.8 units and 4.1 units of erythrocyte suspension replacement, respectively. ${ }^{[14,16,18]}$ In our study, we detected 1.33 units of erythrocyte suspen- sion replacement in the US group. According to these findings, we can say that the decrease in the amount of intraoperative bleeding reduces both intraoperative and postoperative complications of transfusion.

In cases of previa percreta, there is a risk of urinary tract injury, especially if there is lateral or parametrial placental invasion of the uterus is present. For this purpose, preoperative ureteral stent application can be made. But applying ureteral stent before surgery does not eliminate the risk of ureteral and bladder damage. ${ }^{[26}$ We did not apply ureteral stent to any of our cases. Despite this, we have not encountered any ureteral damage. But we detected bladder damage in one case in US group and in one case in hysterectomy group. In both cases, advanced fibrosis was present between the posterior side of bladder and uterine serosa. At two different percreta hysterectomy series, authors reported $5 \%$ and $6.9 \%$ bladder injury ratio. ${ }^{[12,27]}$ In this context, we can say that our rates of bladder injury are in line with the literature. According to our experience, the damage of the serosa overlying the placenta that makes bulging from the anterior surface of the uterus leads to bleeding hard to control and the loss of the bladder dissection plane. This condition may lead to increased bladder complications. We want to emphasize that maintaining the dissection plane of bladder is very important in order to minimize bladder injury.

Satinsky clamps provide temporary vascular occlusion, which are mostly applied in cardiovascular and hepatorenal surgery. We could not find any literature data using Satinsky clamps in percreta surgery. The advantages of these clamps are practical and easy to use, do not damage tissues and can be removed when desired. ${ }^{[28]}$ In our cases, we have not encountered any complications related to the use of these clamps. In percreta cases with very high risk of bleeding, we can say that the use of these clamps is safe, easy, and may contribute to reduce the amount of intraoperative bleeding according to our experience.

The limitations of our study were retrospective design and low number of patients. Subgroup analyses were not robust due to the low number of cases. The strength of our study is the first to describe a new surgical technique for temporary blockage of bilateral uterine and uteroovarian arteries with Satinsky clamps that potentially contributes to a reduction in intraoperative blood loss and transfusion rates in uterine sparing surgery. 


\section{Conclusion}

In our study, we found that US surgery reduces intraoperative blood loss and transfusion rate in PPP patients with anterior placental invasion compared to hysterectomy. The temporary blockage of bilateral uterine and uteroovarian arteries with Satinsky clamps may contribute to the literature and future projections in PPP surgery.

Funding: This work did not receive any specific grant from funding agencies in the public, commercial, or not-for-profit sectors.

Compliance with Ethical Standards: The authors stated that the standards regarding research and publication ethics, the Personal Data Protection Law and the copyright regulations applicable to intellectual and artistic works are complied with and there is no conflict of interest.

\section{References}

1. Usta IM, Hobeika EM, Abu Musa AA, Gabriel GE, Nassar AH. Placenta previa-accreta: risk factors and complications. Am J Obstet Gynecol 2005;193:1045-9. [PubMed] [CrossRef]

2. Society of Gynecologic Oncology; American College of Obstetricians and Gynecologists and the Society for Maternal-Fetal Medicine; Cahill AG, Beigi R, Heine RP, Silver RM, Wax JR. Placenta accreta spectrum. Am J Obstet Gynecol 2018;219:B2-16. [PubMed] [CrossRef]

3. Zhang H, Dou R, Yang H, Zhao X, Chen D, Ding Y, et al. Maternal and neonatal outcomes of placenta increta and percreta from a multicenter study in China. J Matern Neonatal Med 2019;32:2622-7. [PubMed] [CrossRef]

4. Polat I, Yücel B, Gedikbasi A, Aslan H, Fendal A. The effectiveness of double incision technique in uterus preserving surgery for placenta percreta. BMC Pregnancy Childbirth 2017;17:129. [PubMed] [CrossRef]

5. Silver RM, Landon MB, Rouse DJ, Leveno KJ, Spong CY, Thom EA, et al.; National Institute of Child Health and Human Development Maternal-Fetal Medicine Units Network. Maternal morbidity associated with multiple repeat cesarean deliveries. Obstet Gynecol 2006;107:1226-32. [PubMed] [CrossRef]

6. Silver RM, Fox KA, Barton JR, Abuhamad AZ, Simhan H, Huls CK, et al. Center of excellence for placenta accreta. Am J Obstet Gynecol 2015;212:561-8. [PubMed] [CrossRef]

7. Palacios Jaraquemada JM, Pesaresi M, Nassif JC, Hermosid S. Anterior placenta percreta: surgical approach, hemostasis and uterine repair. Acta Obstet Gynecol Scand 2004;83: 738-44. [PubMed] [CrossRef]

8. Ratiu AC, Crisan DC. A prospective evaluation and management of different types of placenta praevia using parallel vertical compression suture to preserve uterus. Medicine (Baltimore) 2018;97:e13253. [PubMed] [CrossRef]
9. Turan OM, Shannon A, Asoglu MR, Goetzinger KR. A novel approach to reduce blood loss in patients with placenta accreta spectrum disorder. J Matern Neonatal Med 2019 Aug 27;1-10. doi:10.1080/14767058.2019.1656194 [PubMed] [CrossRef]

10. Abo-Elroose AA-E, Ahmed MR, Shaaban MM, Ghoneim HM, Mohamed TY. Triple P with T-shaped lower segment suture; an effective novel alternative to hysterectomy in morbidly adherent anterior placenta previa. J Matern Neonatal Med 2019 Oct 15;1-5. doi:10.1080/14767058.2019.1678145 [PubMed] [CrossRef]

11. Sumigama S, Itakura A, Ota T, Okada M, Kotani T, Hayakawa H, et al. Placenta previa increta/percreta in Japan: a retrospective study of ultrasound findings, management and clinical course. J Obstet Gynaecol Res 2007;33:606-11. [PubMed] [CrossRef]

12. Camuzcuoglu A, Vural M, Hilali NG, Incebiyik A, Yuce $\mathrm{HH}$, Kucuk A, et al. Surgical management of 58 patients with placenta praevia percreta. Wien Klin Wochenschr 2016;128:360-6. [PubMed] [CrossRef]

13. Palacios-Jaraquemada JM, Fiorillo A, Hamer J, Martínez M, Bruno C. Placenta accreta spectrum: a hysterectomy can be prevented in almost $80 \%$ of cases using a resective-reconstructive technique. J Matern Neonatal Med 2020 Jan 26;1-8. doi:10.1080/14767058.2020.1716715 [PubMed] [CrossRef]

14. Karaçor T, Bülbül M, Nacar MC, Kirici P, Peker N, Sak S, et al. The parameters affecting the success of uterus-sparing surgery in cases of placenta adhesion spectrum disorder. J Matern Neonatal Med 2021;34:1091-8. [PubMed] [CrossRef]

15. Kilicci C, Ozkaya E, Eser A, Bostanci EE, Sanverdi I, Yayla $\mathrm{CA}$, et al. Planned cesarean hysterectomy versus modified form of segmental resection in patients with placenta percreta. J Matern Neonatal Med 2018;31:2935-40. [PubMed] [CrossRef]

16. Karaman E, Kolusarı A, Çetin O, Çim N, Alkış İ, Yıldızhan R, et al. Local resection may be a strong alternative to cesarean hysterectomy in conservative surgical management of placenta percreta: experiences from a tertiary hospital. J Matern Neonatal Med 2017;30:947-52. [PubMed] [CrossRef]

17. Acar A, Ercan F, Pekin A, Elci Atilgan A, Sayal HB, Balci O, et al. Conservative management of placental invasion anomalies with an intracavitary suture technique. Int J Gynaecol Obstet 2018;143:184-90. [PubMed] [CrossRef]

18. Cirpan T, Akdemir A, Okmen F, Hortu I, Ekici H, Imamoglu M. Effectiveness of segmental resection technique in the treatment of placenta accreta spectrum. J Matern Neonatal Med 2019 Dec 12;1-7. doi:10.1080/14767058.2019.1702019 [PubMed] [CrossRef]

19. Peng W, Shen L, Wang S, Wang H. Retrospective analysis of 586 cases of placenta previa and accreta. J Obstet Gynaecol (Lahore) 2019;40:609-13. [PubMed] [CrossRef]

20. Matsuzaki S, Yoshino K, Endo M, Kakigano A, Takiuchi T, Kimura T. Conservative management of placenta percreta. Int J Gynecol Obstet 2018;140:299-306. [PubMed] [CrossRef]

21. Fratto VM, Conturie CL, Ballas J, Pettit KE, Stephenson ML, Truong YN, et al.; University of California fetal Consortium. Assessing the multidisciplinary team approaches to placenta 
accreta spectrum across five institutions within the University of California fetal Consortium (UCfC). J Matern Neonatal Med 2019 Oct 24;1-6. doi:10.1080/14767058.2019.1676411 [PubMed] [CrossRef]

22. D'Souza DL, Kingdom JC, Amsalem H, Beecroft JR, Windrim RC, Kachura JR. Conservative management of invasive placenta using combined prophylactic internal iliac artery balloon occlusion and immediate postoperative uterine artery embolization. Can Assoc Radiol J 2015;66:179-84. [PubMed] [CrossRef]

23. Carnevale FC, Kondo MM, de Oliveira Sousa Jr W, Santos AB, da Motta Leal Filho JM, Moreira AM, et al. Perioperative temporary occlusion of the internal iliac arteries as prophylaxis in cesarean section at risk of hemorrhage in placenta accreta. Cardiovasc Intervent Radiol 2011;34:758-64. [PubMed] [CrossRef]

24. Ji W, Wang W, Sun S, Wu J, Xu W, Tao D, et al. A clinical analysis of uterine artery embolisation in the treatment of placenta praevia or placenta praevia state. J Obstet Gynaecol 2014;34:585-7. [PubMed] [CrossRef]

25. Ballas J, Hull AD, Saenz C, Warshak CR, Roberts AC, Resnik $\mathrm{RR}$, et al. Preoperative intravascular balloon catheters and surgical outcomes in pregnancies complicated by placenta accreta: a management paradox. Am J Obstet Gynecol 2012;207:216.e15. [PubMed] [CrossRef]

26. Committee on Obstetric Practice. Committee opinion no. 529: placenta accreta. Obstet Gynecol 2012;120:207-11. [PubMed] [CrossRef]

27. Sak S, Barut M, Incebiyik A, Uyanikoglu H, Hilali N, Sak M. Management of peripartum hysterectomies performed on patients with placenta percreta in a tertiary central hospital. J Matern Neonatal Med 2019;32:883-8. [PubMed] [CrossRef]

28. Yang Y, Lai ECH, Fu SY, Gu FM, Li PP, Lau WY, et al. A prospective randomized controlled trial to compare two methods of selective hepatic vascular exclusion in partial hepatectomy. Eur J Surg Oncol 2013;39:125-30. [PubMed] [CrossRef]

This work is licensed under the Creative Commons Attribution-NonCommercial-NoDerivs 4.0 Unported (CC BY-NC-ND4.0) License. To view a copy of this license, visit http://creativecommons.org/licenses/by-nc-nd/4.0/ or send a letter to Creative Commons, PO Box 1866, Mountain View, CA 94042, USA.

Publisher's Note: The content of this publication does not necessarily reflect the views or policies of the publisher, nor does any mention of trade names, commercial products, or organizations imply endorsement by the publisher. Scientific and legal responsibilities of published manuscript belong to their author(s). The publisher remains neutral with regard to jurisdictional claims in published maps and institutional affiliations. 